According to the label accompanying the shells, they were found in sinking a Government well in the Murray River Flats, on the road from the Burra-Burra Mines to the Great Bend of the Murray River, about half way (thirty miles) between the two points named. For the determination of the Foraminifera I am much indebted to Mr. H. B. Brady, F.R.S., and to Prof. G. S. Brady, for a like examination of the Ostracoda.

The Foraminifera are-

Biloculina contraria, D Orb. , depressa, D'Orb.

" elongata, D'Orb.

, ringens, Lamk.

Cornuspira foliacea, Phil.

" involvens, Reuss.

Cristellaria rotulata, Lamk.

Glandulina lavigata, D'Orb.

Hauerina compressa, D'Orb.

Orbitolites complanatus, Lamk.

Planorbulina reticulata, Czjzck. " Ungeriana, D'Orb.

\author{
Polystomella craticulata, F. \& M. \\ , macella, F. \& M. \\ Pulvinulina elegans, D'Orb. \\ Quinqueloculina agglutinans, D'Orb. \\ $" \quad$ secans, D'Orb. \\ " seminulum, Linn. (var.) \\ Rotalia Soldanii, D'Orb. \\ " subrotunda, Montagu. \\ Spiroloculina canaliculata, D'Orb. \\ Triloculina oblonga, Montg. \\ , tricarinata, D'Orb. \\ Truncatulina lobatula, W. \& J.
}

The Ostracoda are-

Bairdia ovata, G. Brady.

Macrocypris acuminata, Reuss.

Cythere Normani, G. Brady. Puracypris decora, G. Brady.

Prof. Brady remarks that these appear to be perfectly identical with the Ostracodal fauna now living in the seas of Australia and the Malay Archipelago. A few other Ostracoda were also present, probably new; but from the paucity of individuals it was scarcely advisable to describe them at present.

The Murray River Flats consist of a flat scrubby plain extending from the Murray River on the East, between the Great Bend and Lake Victoria, to the South Australian Chain, or Cape Jervis Range, on the West, and must be composed of strata, geologically speaking, of no great antiquity; in fact, the whole of that portion of the southern coast of Australia bears evident traces of recent upheaval, even in places now going on.

Edinburgh, May, 1876.

R. Etheridge, Jun.

\title{
LLANDOVERY ROCKS IN THE LAKE DISTRICT.
}

Sir,-CThe assertion made by Mr. Aveline in the last Number of the Geol. Mik., that " both the Upper and Lower Llandovery Rocks are absent in the Lake District," is not borne out by the researches of other observers, nor is it in accordance with the published statements of such well-known authorities as Prof. Harkness and Dr. Nicholson. The Coniston Limestone is generally acknowledged to be the equivalent of the Bala Timestone, and the succession up to this point is quite clear. Upon this limestone the Graptolitic Mudstones, according to Mr. Aveline, rest "with a very slight unconformity," and he considers the mudstones to be the equivalents of the Tarannon shales of Wales. The Tarannon shales he considers form the base of the Wenlock series, and hence to be higher in the scale than the Upper Llandovery or May Hill sandstones. Now, by a strange coincidence, we find the following statement by Dr. 
Nicholson in the same Number of the Magazine, p. 216 :-_"It is highly satisfactory to me to know that Dr. Linnarsson's investigations fully corroborate the view always maintained by Prof. Harkness and myself on this matter-namely, that the Coniston Mudstones are indubitably inferior to the true Upper Silurian rocks." In the same paper he mentions several facts in support of this view, and I certainly think the evidence at present tends strongly to show that these mudstones are considerably lower in the succession than Mr. Aveline would have us believe. The Coniston mudstones, flags, and grits collectively appear to represent the Upper and Lower Llandovery rocks of part of Wales, and probably also the Tarannon shales and Denbighshire grits. These latter are not, in my opinion, to be placed altogether above the Llandovery rocks, but to a great extent to be considered their equivalents. That difficulties will continually arise in any attempt that is made to correlate these rocks in different districts there can be no doubt, and the reason is obvious when we recollect how great the changes were which took place at the time these were deposited. In the May Number of the Geol. MAG., pages 215 and 216, I attempted to explain what the result of necessity would be in those areas which were undergoing these great physical changes, and the effect on the deposits, and the order of succession. It is tolerably clear that the uplifting of the seabottom in Cumberland, and in North Wales, occurred after the Upper Bala and Coniston Limestone had been deposited, for the succession is perfectly elear in both areas up to that point. The uplifting which now occurred raised the sea-bottom above water-level in parts of those areas only, and to unequal heights. Hence portions remained submerged, some became shore-lines and shallows, and others were raised sufficiently to become dry land. It is clear, therefore, that as these parts were again gradually submerged, sediments were laid down more or less unconformably upon the uplifted portions, and that the character of the sediments and the thicknesses would vary greatly even within very narrow limits. The denudation of these uplifted portions would also furnish abundant material, and so the sediments would be heaped up rapidly in the surrounding sea. In the Welsh area the Lower and Upper Llandovery rocks of South Wales were heaped up at this time, and as this part continued under water during the whole period, the sediments there show perfect conformability throughoul. But as we advance nearer towards the uplifted portions, the series gradually thin out, and an uncouformity may show itself at almost every point in the succession up to near the close of the Upper Silurian. The Tarannon shales of the extreme North of Denbighshire and the Denbighshire grits, being entirely the result of the denudation of these islands, were also heaped up chiefly at the time the Llandovery rocks were deposited in South Wales; consequently, for the most part they may be correlated with them. The same order in the deposits appears to be shown in Cumberland, and I entertain no doubt but that at some part of that area the same general succession may be recognized.

Heriot House, Hendon. HeNRY Hicks. 